\title{
A politics of affect: Re/assembling relations of class and race at the museum
}

\author{
Abstract \\ This article takes as its focus a politics of affect and its potentially transformative effects. Drawing \\ on feminist new materialism and the process philosophy of Deleuze, I map moments in which this \\ politics is enacted as school children encounter museum exhibits designed to address issues of class \\ and race. Taking affect to be a matter of the capacity of bodies to affect and be affected, I attend to \\ how the body's power of acting is increased or diminished through these encounters. Affect emerges \\ as central to negotiations around issues relating to class and race, with some assemblages produced \\ being particularly able to effect changes in capacities. Politics presents as a process of affective \\ encounter through which dominant cultural norms of class and race can be contested and their \\ exclusions 'undone'. The argument is made that a politics of affect has the potential to unsettle \\ normative power relations and address issues of social inequality and do so in an affirmative way. \\ And, that attending to affect extends identity-based framings of class and race by bringing the \\ constitutive role and contribution of the material, the micropolitical and the radically relational into \\ view.
}

Keywords: affect, politics, assemblage, class, race, materialist analysis, affirmative thinking 


\section{Introduction}

Little Lonsdale Street wasn't really rich, and they didn't have, you know, that good houses. So they lived and they ... yeab they lived in such small houses, but they still ... they still lived in it and they didn't care if it was big or not, they just wanted a house (Joseph, student, Year 4).

I felt terrible. Like I really felt the side of the victim watching that, and so I felt really bad, and I felt maybe like guilty for doing the same thing, like maybe I do that (Nelly, student, Year 10).

These comments, made by two students during interviews about their experience of exhibits when visiting Museums Victoria, Australia's largest public museum organisation, invite consideration of how affects play into identity practices and their politics, here, concerning class and race. Thus, Joseph a student from a Catholic primary school, upon experiencing how poor, working class families lived in an area of Melbourne with a reputation for being a slum, is moved to report that 'they still lived in it', affectively attuning to class differences and disadvantage. And, Nelly, a student from an independent girls' school, upon viewing a racist incident filmed on a Melbourne tram, reports 'I felt terrible ... maybe like guilty', affording the idea that affects 'do' racial identity work.

This article aims to explore how normative identities primarily concerning class and race can be challenged in museums that engage with social issues and promote social change, and the role and contribution of affect in this. ${ }^{1}$ As Zerilli (2015, p.281) claims, 'on a generous interpretation, affect theory is an attempt to explain the tenacity of oppressive social norms and to hold out the possibility of a novel and politically progressive response'. Or, as Kristensen (2016, p.12) argues, 'affects embody possibilities for creation, change and transformation with respect to the given state of

\footnotetext{
${ }^{1}$ For the purposes of this paper, the museum serves more as an institutional context for the research reported than a focus in itself. Nonetheless, this research contributes to a growing interest in museum studies in affect and how it can be cultivated to promote sociopolitical work (see for example, Smith, 2021; Witcomb, 2015).
} 
affairs of the present'. With regard to the data snippets above, attention is drawn away from class and race as all-encompassing structural categories - the given state of affairs - in favour of the analysis of affective capacity - the intensities that power the body to move and be moved (Colebrook, 2002). Reported respectively in the form of 'just want(ing) a house' and feeling 'maybe like guilty for doing the same thing', it is this capacity that is at the heart of a politics of affect. And, this heart is not an exclusively human one: material practice enters the story in the form of objects, spaces and places. Thus, going beyond a focus on people and human subjects formed as classed and raced - attending to the constitutive social significance of materiality and affects - I experiment with intervening in how one might navigate and unsettle normative constructions of class and race.

Affect has a twofold character. It has the potential to be both normative and transformative (Dernikos, Lesko, McCall, \& Niccolini, 2020, p.9; Hemmings, 2005). The contemporary interest in affect, or what Hemmings (2005, p.550) calls 'affective celebration', can lead to over claiming, particularly with regard to its transformative potential. I have cause to tread carefully if interested in running affective interference on normative categories of class and race when affect can serve to sustain and reproduce them. The privileging of particular affective capacities is not my preference, nor is an account of affect in which normativity plays no part. I am guided by Spinozist concepts of affect and their take-up by Deleuze (1988; Deleuze and Guattari 1987) where affect is formulated as the power 'to affect and be affected' and characterised by an increase or decrease of power. For Spinoza and Deleuze, normative considerations are defined in terms of the affective constitution of bodies. As Braidotti (2019b, p.157) has it, 'the normative distinction between good and evil is replaced with that between affirmation and negation'. The focus falls on the affective capacities of bodies within a network of relations. 
The relations that a given body enters into can involve humans and more than humans inasmuch as in Deleuzian philosophy bodies can take the form of human bodies, objects, spaces, places, natural environments and concepts or bodies of knowledge. Norms of class and race that prevail can be challenged along any of these bodily lines, that is discursively, affectively and materially. Affective encounters within museum spaces such as the exhibition space in which Nelly contends with racialised relations on a Melbourne tram, have the power to affect positively and negatively and it is only the different capabilities of the bodies involved and the relations that they enter into that will decide the outcome. A processual relational ontology is in play.

The structure of the article is as follows. After initial discussion of affect as forwarded in DeleuzianSpinozan philosophy where the focus is on the ontological positivity of entities (Braidotti, 2019a), attention is given to what a materialist approach to inquiry, including a feminist materialist approach (Barad, 2007; Braidotti, 2019a; Manning, 2016), might provide. Drawing from the philosophic work of Deleuze, assemblage thinking (Deleuze and Guattari, 1987) is outlined and then employed with regard to empirical material gathered over the course of a qualitative research project set within Museums Victoria. Vignettes embodying the practice of a politics of affect in varying exhibition spaces are described. In undertaking the analytic work, the Spinozist concepts of potentia (empowerment, augmentation) and potestas (entrapment, restriction) are used to explore force relations that generate assemblages. The central issue explored in the empirical material concerns how a politics of affect is practised in the context of class and race relations and what it produces regarding these relations and student subjectivities at and beyond the museum.

\section{On the politics of affect: Stating a positive passion}


Interrupting the flow of negativity, disengaging from it by stating a positive passion - 'I would prefer not to' - is a way of constructing critique as affirmation. It's a way of saying 'no', actually. But it is not a dialectical 'no' that blocks, cuts the relation and seeks antagonistic confrontation as the motor of change. It is a 'no' that relates (Braidotti, 2019a, p.472).

Recent scholarship on affect has begun to move away from psychological accounts that assume it lies within individuals, towards relational ones whereby affect is seen as coming from bodies understood as 'assemblages of forces' (Bolanos, 2007, p.119). Thus, a body is a force and it could be anything: 'an animal, a body of sounds, a mind or an idea; it can be a linguistic corpus, a social body, a collectivity' (Deleuze, 1988, p.127). In this rendering, class and race are bodies or assemblages of forces. When attending to class and race relations in this article, categories of class and race are taken to be both identity-based and 'physical entities performed by human bodies in relation to other bodies and objects' (Andrews, 2019, p.1112). Identity is defined in relation to differences of class and race (and ethnicity, gender, age and so on) that socially differentiate and divide. While one is not so much a member of fixed and singular social groups (e.g. 'the working class') as one does class and race relations, or better, is caught up in, or a conduit for, their doing, in identity-based framings, identities are marked as social (human) and as external to one another, prompting binary thinking and the creation of counter-identities (Dolphijn and van der Tuin, 2012, p.99). ${ }^{2}$ Underscored by an ontology of mutual specification, an assemblage framing challenges this scheme. The classed or raced

\footnotetext{
${ }^{2}$ From a materialist posthuman perspective, the complex concepts of identity and identity politics have been much debated (see for example, Braidotti, 2019b; Dolphijn and van der Tuin, 2012). Posthuman thinking is post-identitarian: 'it turns the self away from a focus on its own identity' (Braidotti, 2019b, p.77). Originating in Black Feminist Thought, identity politics takes place at the site where race, gender and class intersect and coalitions can be built (Taylor, 2017). While attending to materiality and relationality, an intersectional model of identity presumes the separability of categories of identity. Posthuman thinking sees the inter-relation of phenomena such as sex/gender as constitutive of the identity of each (Braidotti, 2013, p.80). Accordingly, class, race and other identity differences embed 'difference as the principle of not-One' (ibid., p.100).
} 
subject is reframed as a process or assemblage (Braidotti, 2015, p.35) drawing attention away from discrete identity categories in favour of embodied and embedded affective and material encounters.

Class and race are conceived as on-the-ground practical arrangements (assemblages) comprising bodies, affects which stick to bodies, material resources, discourses, memories, imaginings and more. This conception affords sensitivity to the complex doing of difference rather than reducing it to predefined categories. It does not disavow the idea that relations of class and race 'clot' and re-produce themselves as social structural determinants. There are institutional forces and habit-formations with regard to class and race that (re-)produce existing social relations. The institutional force relations of the neoliberal university (Moss, Kern, Hawkins, \& Falconer Al-Hindi, 2018) and the repetitive, sedimented practices of racism within the family (Nelson, 2020, p.2) are cases in point. Thinking relations of class and race as assemblages affords attention to their emergence and ongoing formation and possible de-formation (e.g. de/colonisation). With its strong resemblance to power, its capacity to restrict and augment, affect can form assemblages that are particularly powerful, able to run interference on or affectively rupture normative power relations. Primarily about change, 'the concept of affect is politically oriented from the get go' (Massumi, 2015, p.viii).

In forwarding a social relational account of affect, von Scheve (2018, p.55) emphasises its relational and bodily character: 'Although affect refers to bodies and modes of bodies, it cannot meaningfully be conceived of as something an individual body "has", but rather as a quality of different types of relations through which interrelated bodies are constituted and constantly reshaped.' In referencing 'modes of bodies' and the 'quality of different types of relations', directions are pointed towards a politics of affect. Like affect, politics is a performative matter; its outcomes cannot be decided in advance of practice. It can only be defined nominally 'as, for instance, an effort to select and 
organize good encounters but what these encounters constitute in reality cannot be known in advance' (Kristensen, 2016, p.23). No guarantees attach to the effort to organise good, or better, affirmative encounters: given the indeterminacy of a body's potential, 'a certain degree of experimentation is necessary in order to realize the power it possesses' (Sparrow, 2010, p.167).

Informed by Spinoza's Ethics (Spinoza, 1994), a normative distinction is drawn in Deleuzian philosophy between modalities of power. Power can assume the form of entrapment (potestas, decrease of bodily capacity) and/or empowerment (potentia, increase of bodily capacity). Potestas and potentia can be understood respectively as 'power over' and 'power to': a force-relation that is, on the one hand, external/reactive/transcendent (potestas) and, on the other, immanent, having become cause of itself, active (potentia) (Seigworth 2020). ${ }^{3}$ The form that power takes is not decided in advance of practice. Scholars concerned to 'flesh out' a politics of affect (Massumi, 2015; Thrift, 2004) attest to this. Thus Massumi (2015, p.vii) states that 'affect is only understood as enacted'.

Contrary to the longstanding critical interest in the social sciences of power as repressive of certain social identities (e.g. non-normative genders, classes, sexualities), power in the context of affect is indeterminate; it can play out by way of threats and possibilities. Following Spinoza, Deleuze is interested in 'determining which bodies interact in ways that are mutually empowering; which bodies interact in ways that are mutually enervating; and which bodies interact in such a way that only some are strengthened while the others are weakened' (Sparrow, 2010, p.178). A politics of affect thus involves attuning to how the body's power of acting is increased or diminished in its encounters. Accordingly, it requires 'inquiring into 1) the composition of bodies and their capacities to affect and

${ }^{3}$ This formulation of potestas and potentia was provided by Greg Seigworth when acting as a reviewer of this article. Seigworth signs his reviews and I am grateful for his elaboration regarding these modalities of power. 
be affected, 2) the role of relations between individual or collective bodies in the engagement of these capacities, and 3) the question of how to compose relations capable of sustaining individuals and communities in active and affirmative modes of existence' (Stephano, 2017, p.326). And, refusing oppositional thinking, stating a positive passion (Braidotti, 2019, p.472) in the form of saying 'no', where this 'no' is not adversarial and exclusionary, is one way of composing these relations.

\section{Materialist modes of analysis: An assemblage analytic}

Increased attention is being paid to materiality and affectivity in social sciences and humanities research by way of the take up of new materialism (Anderson and Perrin, 2015; Dolphijn and van der Tuin, 2012; Fox and Alldred, 2018). As MacLure (2018, p.94) has it, 'materially informed work is going on under a variety of names: material feminism, new materialism, new empiricism, posthuman studies, actor network theory, affect theory, process philosophy, the ontological turn'. Process philosophy includes the philosophical work of Deleuze and aligns with feminist materialist articulations of affect and politics of affect (see in particular, Braidotti, 2009, 2019a; Manning, 2007, 2016). As Fox and Alldred (2018) describe, 'DeleuzeGuattarian materialism regards human bodies and all other material, social and abstract entities as relational, having no ontological status or integrity until drawn into "assemblages". Thus, social and abstract entities like class and race are not defined as power structures prior to their emergence in assemblages. And, once these entities are drawn in, they do things, effect changes in capacities. An example of class as assemblage is discussed in the analysis section below whereby the Year 4 student, Joseph, quoted in the introduction to this article, is filmed putting up curtains that had fallen down in one of the Little Lon 'slum' houses. Affect as a material-cum-political process exerts force bringing what I call a more-than-slum 
assemblage into being. Albeit that entities do not pre-exist their assemblages, there are modes of relating, patterns of assembling, that concretise, producing durable effects. For example, race infused patterns of 'towardness' and 'awayness' form in bodies, both marked and unmarked (Ahmed, 2014).

Following Deleuze and Guattari (1987), an assemblage is 'a collection of heterogeneous elements. These elements could be diverse things brought together in particular relations ... But the elements that make up an assemblage also include the qualities present ... and the affects and effectivity of the assemblage: that is, not just what it is, but what it can do' (Wise, 2011, p.92, original emphasis). Assemblage theory leads to scholars asking fundamental questions of assemblages such as: What is in-situ? What is arriving or leaving? What is passive or active? What is interacting with what and how? (Andrews, 2019, p.1113), providing an 'in' to this doing. Nonsubjective dimensions are critical to grasping the complex relations that constitute a politics of affect, a politics that among other formulations such as affirmative politics (Braidotti, 2015), can be called a politics of what (Mol, 2002, p.170).

\section{Data and methods}

My analysis draws on two bodies of data produced over the course of a small-scale, author-led, oneyear study (2013-2014) of learning affectively at the museum. The methodological approach adopted was informed by the emerging interest in qualitative research in materialist perspectives (Ellingson and Sotirin, 2020; Ringrose, Warfield, \& Zarabadi, 2019; Snaza, Sonu, Truman, \& Zaliwska, 2017). Initially, video-based case studies of 'naturally' occurring interactions in selected exhibition spaces at Museums Victoria (https://museumsvictoria.com.au/museum-at-home) were undertaken with groups of children drawn from three schools (government and non-government). Extensive use was 
made of video, including (i) whole group camerawork by two technicians of student groups (forty students altogether) within exhibition spaces, and (ii) individual body camerawork via GoPro action cameras which recorded students' embodied movement through these spaces and 'captured' what they saw and said individually over the course of the filming. The choice of video methods was purposeful inasmuch as the project concerned capturing children's embodied encounters with exhibits embedding relations of class and race. Paired interviews were then conducted with two children (selected by the visiting teacher) from each school immediately after the filming. These interviews were both video-stimulated and video-recorded. Using as catalyst the video record from the GoPro cameras, the children were invited to make a reconstructive account of their encounters, towards gaining reflective insight into the dynamics of class and race. Accounts were guided by questions such as: 'Can you tell me about what you best liked doing during the activity filmed?'; 'As you made your way through the exhibition, what jumped out at you as something you might like to look at again or take part in? What left the strongest impression on you? Can you say why? Clearance from the relevant institutional ethics committees was gained prior to undertaking the filming. This clearance included gaining parental consent and child assent to both filming and the educational use of the images produced from the research. Provision was made for filming to occur at the museum at times when members of the visiting public were not present.

In undertaking an assemblage analysis, I offer two vignettes detailing moments where a politics of affect came to the fore. Assuming that the departure point for analysis is in the performative process, the questions guiding my data making (Ellingson and Sotirin, 2020) are: What is affect doing, how is it moving and what are its power and identity effects? And, What capacities can affective political assemblages produce within a museum context? 


\section{Affective encounters: Attuning to powers of acting}

Vignette 1 - Little Lon: '(P)art of the window was like curtained, which is like it wasn't connected'

A historic recreation of two workers' cottages in an inner-city area of Melbourne with a reputation for being a slum riddled with poverty, prostitution and drug addiction, the Little Lon exhibit at Melbourne Museum invites attuning to powers of acting, politically and affectively. Recreating the domestic conditions of Melbourne's working poor in the mid-to-late $19^{\text {th }}$ century, one cottage shows extreme poverty while the other is the home of a family who have some material comforts, as shown respectively in Figures 1 and 2.

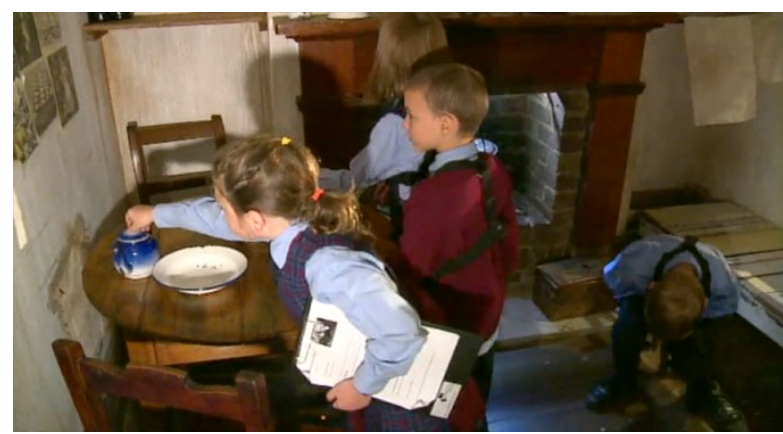

FIGURE 1: Children exploring the contents of the living room of the poorer cottage.

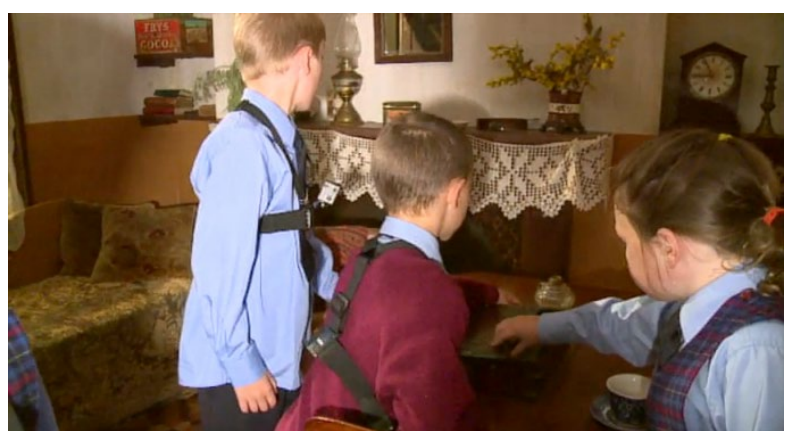

Figure 2: Children exploring the contents of the living room of the poor but aspirational cottage.

Source: Stills taken from film footage, Melbourne Museum.

Upon entering the cottages, the Year 4 primary school children (average age of 9) were observed handling domestic items and trying out items (stools, sofas) for size and comfort towards, I assume, getting a 'fix' on the experience of living as a poor family in past times. In physically handling these items, the children were moved, attuned to the affective resonance of the material and historical world they were encountering. Affect is clearly in evidence through connections made between 
children's bodies and the cottages' objects. Thus distaste was expressed for the crowded conditions of the poorer cottage and specifically for the sanitary pan toilet located in the backyard shared by the cottages, triggering this conversation among a group of four children:

I couldn't live in this place ... so small and, we all have bigger houses and it makes us feel better like, what if we lived here, bit worried ...

Look, it's the toilet.

That's the toilet! Oooh.

Look at the toilet. Imagine ...

Just imagine.

Maybe I don't want to look in there (sanitary pan).

Yeah!

I'm already expecting that this house is poorer than the other house ... just makes you feel so bad for them.

Like the two beds in there are just like squished in to each other, there's like barely any space.

This small group conversation 'captures' the children coming to a view of whether they could live in the cramped conditions of housing for the poor. The affective force of objects is amplified through language, here repetition of phrases such as 'Look, it's the toilet' and 'Just imagine'. The politics mobilised by this affective force centres on the material conditions of inner-city life in times of 'so small' houses. Boundaries are drawn between 'them' and 'us' and 'then' and 'now' with the children favouring the latter: 'we all have bigger houses and it makes us feel better like, what if we lived here, bit worried'. 
With regard to Joseph who was both filmed and interviewed post filming, affective engagement was particularly strong with 'territorialising' spaces of them and us less pronounced:

Little Lonsdale Street wasn't really rich, and they didn't have, you know, that good houses. So they lived and they ... yeah they lived in such small houses, but they still ... they still lived in it and they didn't care if it was big or not, they just wanted a house.

He observed late in the interview that Little Lon reflected:

things that represented fairness, like some of the objects and (living in) Little Lonsdale Street was like (they) shared their stuff because they were really poor. ... if you looked at the backyard(s), they were both connected. ... In the rich house, part of the window was like curtained, which is like it wasn't connected.

In a gesture that I have mulled over for some years, Joseph was filmed putting up curtains that had fallen down in the kitchen of the less poor cottage toward, I take it, making a more 'homely' home for a family, not members of a city slum. Joseph is aware of the political dynamics attached to curtaining, its privatising powers -'In the rich house, part of the window was like curtained, which is like it wasn't connected' - yet the bodily impulse to 'correct' the curtaining is strong. The fallen curtains take Joseph's attention - are affecting - and he in turn affects them and, by extension, the makeup of the cottage. Caught up in intensities that power the body to move and be moved (Colebrook, 2002) - 'they lived in such small houses, but they still ... they still lived in it and they didn't care if it was big or not, they just wanted a house' - he acts in relation with the curtains and the cottages. Assorted things (objects, affects, spaces, people) are brought together such that an 
affective political assemblage forms. The cottages are thought and done as distinct - 'In the rich house, part of the window was like curtained' - and importantly, as more than slum dwellings.

Restoring the fallen curtains can be considered a minor gesture, in the sense in which Manning (2016, p.1) frames this concept: 'The minor gesture, allied to Gilles Deleuze and Felix Guattari's concept of the minor, is the gestural force that opens experience to its potential variation. It does this from within experience itself, activating a shift in tone, a difference in quality'. The affective encounter had by Joseph with the cottages was discernibly different to the encounters had by the other children. While sympathetic to the plight of the working poor, they tended to stand outside their experience: 'I couldn't live in this place ... so small'. The qualitative difference made in Joseph's act of rehanging the curtains, the affects involved, are care, and what I will call critical empathy, manifested through movement toward the Other - so-called slum precincts and dwellings.

The assemblage that forms and its possible effects can be sketched as: more-than-slum cottagesJoseph_curtains - empathy_care-increased capacity. The more-than-slum assemblage has the potential to challenge discourses of deficit surrounding slum living and the affects attaching to these discourses (e.g. distaste, disgust). The Little Lon exhibit invites consideration of issues of systemic disadvantage and entrenched poverty. It opens a space for countering a homogenising slum narrative apparent in the $19^{\text {th }}$ century and continuing to exist in many countries today. It embeds the tension between major and minor which Manning (2016, p.1) describes in this way: 'The major is a structural tendency that organizes itself according to predetermined definitions of value. The minor is a force that courses through it, unmooring its structural integrity, problematizing its normative standards'. The affective, the material and the mundane are at the core of Joseph's minor gesture, a gesture attuned to unsettling the major, the seemingly self-evident idea of Little Lon as a slum. 
Any practice and politics of affect is contingent on the type of assemblage through which it forms and to which it is attached. The educative aim of the Little Lon exhibit is to produce critical awareness of past living conditions in the context of relations of class, race and so on. If potentia (increase of bodily capacity, 'power to') prevails, this aim would, it is likely, take in connecting with the cottages as 'more than slum'. If not necessarily achieved by the other children, it is achieved by Joseph in relation with curtaining, a consequential affective material act embedding a politics that is immanent: a politics that 'does not have the full force of a preexisting status, of a given structure, of a predetermined metric' (Manning, 2016, p.2). I posit that the lack of givenness of this politics is its strength. It remains open to where it might take Joseph, the other children, the cottages and the socalled slum. Upon return to school, the children might debate the issue of slum living.

\section{Vignette 2 - Tram Scenario: '(L)ike there's nothing wrong with sitting next to whoever'}

Tram Scenario is a video that invites viewers to see a racist incident, recreated from 'real life'. It plays out in a tram-like structure in which visitors to Melbourne’s Immigration Museum can sit and aims to have school visitors address questions like: Who fits in? Who doesn't? And who gets to decide? Nelly, the Year 10 student (average age of 15) from an independent girls' secondary school who features in this article's opening, tells the Tram Scenario at interview in these terms:

Well what happens is ... this guy ('Rob'), he walks on a tram, and this (other guy, 'Ibrahim') ... I think he's Aboriginal, or I think that's what I took from it, but he makes like ... I think he makes a spare seat for the guy to sit down next to him, but then the man doesn't sit next to him. And so ... and then he (Rob) starts ... he starts drinking, and then the Aboriginal guy gets on the phone and he starts talking in 
his native language to someone, and he (Rob) goes - 'oh excuse me, you're too loud, can you lower the volume?' And he still wasn't sitting next to him, and then he... and then he just crushed his can and walked out of the tram.

Commenting on the fact that Rob, a middle-aged white Australian male, 'still wasn't sitting next to' Ibrahim, a young man of colour, when invited to do so, Nelly is alert to the affective dynamics of this situation and its ethical and political undercurrents. The video record of the conversation occurring between Nelly and her classmates as they viewed the incident provides insight into the forces encountered. Thus, I hold a copy of the transcript of Tram Scenario against a copy of the girls' conversation as viewers towards making a comparative analysis.

Transcript: Tram Scenario

[Tram sounds and hum of conversations]

[Tram door opening and closing beeps]

[Can cracking open]

[Phone rings]

[Ibrahim speaks in Tigrinya language]

[Drinking sounds]

Rob: Hey, mate... Hey, hey! Can you keep it down a bit? You're a bit loud.

[Can crushing]

[Tram door opening and closing beeps]
Transcript: Viewing the video of Tram Scenario

[Background chat amongst girls]

[Rob enters tram] Aaah. Excuse you!

Get out Oh, my god ... he's so weird

He's slurping really loudly.

Oh my god, just sit down!

Oh! Jeeez. You're a bit loud! Your slurping's

louder than he's talking!

Oooh. He looks drunk ... oh, my god!

[Rob leaves the tram]

The affective nature of negotiations involving racism (Nelson, 2020, p.2) is very apparent. Affect in the form of anger and disgust circulates throughout the conversation and picks up pace over its course producing from the girls' perspectives a strong sense of Ibrahim as victim and Rob as offender. The girls' remarks become increasingly intense and exclusionary, directed as they are at Rob and his 'weird' look. The affective flow takes a material-discursive form with bodies, cultural conventions (volume of voice when on trams), discourses (of ageism and racism), dispositions 
(entitlement on the part of Rob), material objects (can, phone, tram seats, tram-like structure in which the girls sit, video recording) and material practices (taking a phone call, can cracking and crushing) assembling to produce in the viewers movement towards Ibrahim and away from Rob: 'You're a bit loud. Your slurping's louder than he's talking'.

Affect is performative and political. The repeated affective phrases of 'Oh my god', 'Jeeez', and 'Aaah' serve to bring indignation at the abuse suffered by Ibrahim, at the hands of Rob, into effect. There is a rush to judge with judgement and outrage engendering a political process or assemblage that forms around the notion of perpetrator-victim, as Nelly relates at interview:

I felt terrible. Like I really felt the side of the victim watching that, and so I felt really bad, and I felt maybe like guilty for doing the same thing, like maybe I do that. So it made me think about my actions in relation to like what was happening.

In company with her classmates, Nelly, as a political subject, is attuned to how structural racism manifests and ready to call it out: 'Oh my god, just sit down!'. Set within the arrangement (assemblage) of the scripted video with its powers of affective transmission, a politics is practised where boundaries are marked out (perpetrator, victim), positions are taken ('I really felt the side of the victim') and resistance is promoted and collectively and vociferously expressed ('Your slurping's louder than he's talking').

The assemblage of perpetrator-victim produces what Braidotti (2009, p.44) calls the 'traditional equation between political subjectivity and critical oppositional consciousness'. The well-established discourse of power as repressive of non-normative social identities might be thought to be in play. The 
girls identify with Ibrahim on the grounds of race ('the Aboriginal guy') and possibly also on the grounds of age. A strong contrast is drawn in the performance of what I will call (op)positional politics where identities appear fixed and 'hidden'. Little attention is given by the girls to white privilege, both theirs and Rob's which, as I discuss below, could produce an assemblage unlike the individualised perpetrator-victim assemblage. As stated at the outset of the article, affect has the potential to be both transformative and normative (Dernikos, et al., 2020, p.9). Referencing the work of Hemmings (2005), normative here 'means affect's ability to possibly strengthen dominant cultural norms or white, patriarchal ways of knowing, being, and doing' (ibid.). To some degree, this ability would appear to be in play.

At interview however, Nelly's account of the racist incident is less individualised, more nuanced. She takes for re-view the exclusionary action of Rob when not taking the seat offered him by Ibrahim and turns it reflexively back on herself.

Oh I interpreted it (Rob not taking the seat next to Ibrahim) as ... well at first I thought of all the people on my bus, 'cause I catch the bus every day, and how they just ... I don't know why, they just don't sit down in spare seats. I think it's because they don't want to sit next to ... I don't think it's the person, but I think it's just like they don't want to... they want to sit by themselves or with their friends, not someone they don't know.... (W)hen I first started catching the bus, I was like those people, and I didn't want to sit next to other people because they were strangers and I didn't know them, not because they were a different race or something. But then I just started to learn that ... I don't know ... it doesn't really matter, yeah, it's a seat, it's a person, like there's nothing wrong with sitting next to whoever. So it kind of made me think back to that, and how people on my bus still do that. 
Two affective political assemblages are in evidence here; both signal the importance of material practice. Initially, public transport is described as travelling with other people who 'just don't sit down in spare seats. They want to sit by themselves or with their friends' implying an assemblage of: bus_-people—spare seats—distance—strangers. Nelly implies that over time however, she learned that 'it doesn't really matter ..., like there's nothing wrong with sitting next to whoever'. A new assemblage of bus_-people_occupied seats_closeness—whoever, takes form. This assemblage opens out to relationality, difference and diversity in the figure of 'whoever'. In comparison with the perpetrator-victim assemblage, it also has a different speed and tempo - a quieter intensity. Opening out to difference is a matter of time and trust.

Affect and its politics are bodily doings, literally a matter of sitting down in spare seats, or not, and sitting by oneself or with friends, or not - sitting with strangers. Affect is governed and governs in a corporeal material way. Returning to Spinoza's theoretical philosophy, a politics of affect can produce either a diminished or augmented state. Placing distance between those one does not know on public transport ill affords 'opening oneself up to creative affective connections with the Other' (Zembylas, 2006, p.313), here, with 'whoever', with strangers. Ahmed (2010, p.559) usefully expands this point: 'It is through particular encounters we have with this other, as the one whom I am presented or faced with, that we open up the not yet, as the possibility of being faced by other others'. Sitting 'next to whoever', opening oneself to Others, is an affective intervention: albeit mundane, it is a material, political and affirmative act with the potential to increase the power to act.

\section{Towards a politics of affect: On minor gestures and more}


We cannot live outside our bodies, our friends, some sort of human cluster, and at the same time, we are bursting out of this situation. The question which poses itself then is one of the conditions which allow the acceptance of the other, the acceptance of a subjective pluralism. It is a matter not only of tolerating another group, another ethnicity, another sex, but also of a desire for dissensus, otherness, difference. Accepting otherness is a question not so much of right as of desire. This acceptance is possible precisely on the condition of assuming the multiplicity within oneself (Guattari, 1996, p.216).

Somewhat like Nelly, I ask myself what can be learned from the encounter had with the empirical material? Firstly, I 'found' that the relationship between the affective and the political is one of mutual entailment: "they lived in such small houses, but ... they still lived in it and they didn't care ... they just wanted a house'. While an unsurprising finding, inasmuch as 'affect is itself inherently political' (Gregorio and Merolli, 2016, p.936), the idea of mutual entailment is of consequence. If the affective is performative and multiple, so must be the political, entwined as it is with it. One implication of this thinking is that a difference of class and race is not something that self-evidently is or that one individually has; it is 'determined at the level of the encounter' (Ahmed, 2010, p.562).

In attuning to the workings of Tram Scenario, I traced a movement in the empirical material with respect to what has been called 'criticality rather than criticism' (Orlikowski and Scott, 2015, p.703). Contrary to criticism which tends to harden categories and judge and blame, criticality can 'clarify differences and open up lines of exploration and engagement' (ibid.). It is forward-looking, concerned less with what is ('I think he's Aboriginal') than with what might be or become ('it doesn't really matter ..., like there's nothing wrong with sitting next to whoever'). Nelly learns to orient around criticality, clarifying differences between self and Other, friends and strangers, such that these differences are not set in stark contrast to one another. The (op)positional politics of the racist incident viewed via video where the central characters of Rob and Ibrahim are 'pitched' one against 
the other, gives way to a reflection on her own involvement in, and possible complicity with, encounters where racial abuse takes place.

Speculatively, a shift occurs regarding 'accepting otherness' (Guattari, 1996, p.216). This acceptance is not only a question of right - the right of Ibrahim to not suffer abuse - but also of desire; the impulse to accept 'a subjective pluralism', to assume 'the multiplicity within oneself (ibid.). Further to calling out the othering actions of Rob, Nelly looks within. Conceivably, she senses the role that white privilege plays in racial relations: 'I felt maybe like guilty for doing the same thing'. Nelly's unmarked body is a conduit for, if not an agent of, strengthening white ways of knowing/being/doing. Whiteness and 'more than whiteness' are co-implicated and co-produced. Identities multiply and do so immanently, from the complicated inside of things (Deleuze and Guattari, 1987). As Thiele (2014, p.212) claims, 'instead of striving for co-existence with others via processes of recognition', such as recognition of Ibrahim's rights, we need to affirm 'primary relationality-in-difference, of “having-the-other-in-one's skin"”. In other words, affirm a radical relationality. An assemblage other than perpetrator-victim is apparent.

There is a need for (op)positional politics - 'oppositional consciousness is central to political subjectivity' (Braidotti, 2009, p.46) - but politics also needs to be and do more. Affective politics of a criticality rather than criticism kind might be added to the mix. And, a politics where categories tend to harden as a result of being held one against the other, might be given less weight. Braidotti (2018, p.114) is of the view that identity pins you, nails you almost, to locations of power, which usually are binary machines. Gender is the perfect example of that. It is a mechanism of capture. It binarizes the complexity of our sexed existence'. Putting a post-identitarian position, she claims that 
we need a politics that 'turns the self away from a focus on its own identity' (Braidotti, 2019b, p.77), and attends to the significance of structural conditions such as poverty:

(L)ook at broader issues - how we are constituted as subjects of knowledge, of values, and of freedom. We must resist the pull toward identity issues and turn identities into locations out of which we observe the world. We need to address the world ... the issue of the day is not identity politics. ... We need to address basics: poverty, racism and anti-refugee movements, populism’ (Braidotti, Dernikos, Lesko, McCall, \& Niccolini, 2020, p.44-45).

Nelly, I suggest, in her account of travelling by bus, moves towards this. She approaches identity issues in an immanent grounded way, turns them into locations out of which to observe: 'there's nothing wrong with sitting next to whoever'. Politics no longer exclusively concerns identities; it opens out to affects and locations, multiplies its points of purchase on what requires remedying.

Secondly, assemblage dynamics must be traced in their material-discursive 'doings' and specificity to capture the imbrication of the affective and the political and learn a little more about the workings of an affirmative politics. Drawing from the empirical material, I argue that the basis for a productive politics of affect involves augmentation of human and more than human capacities. Thus in the micro moment of Joseph captured on film putting up curtains, affect presents as a material practice that provokes Joseph to act, and act positively, to add something, to create. The minor gesture of re-curtaining is 'affirmative in its force' (Manning, 2016, p.70). It connects him with the material conditions of a slum house and attunes him to assisting this house to become other than its seemingly certain status as slum. The quality of Joseph's practice of curtaining a 'slum house' is careful. Care emerges as a dynamic affect in the encounter had with this house towards sustaining it, 
having it continue and continue to flourish. The affective nature of negotiations around class comes clearly into view, augmenting or filling out identity-based framings in which material practice and a politics of 'power to' are of lesser note.

In line with the minor gesture, a politics of affect is performed by way of stating a positive passion - 'I would prefer not to' (Braidotti, 2019, p.472) - rather than resisting existing power relations and looking to overturn them. 'Affirmative politics is not about an oppositional strategy' (Braidotti, 2009, p.52). It is a way of 'thinking sustainable futures' (ibid., p.45). Joseph, and Nelly in the final instance, say 'no' to oppositional strategies concerning class and race in their separate and different ways. Thus, Nelly's professed movement towards 'whoever', when taking her school bus, provides a sense of how politics can be done positively, and what this might yield. In sum, and as Braidotti (2009, p.53) argues, 'politics becomes multiple micro-political practices of daily activism or interventions in and on the world we inhabit' such as putting up curtains and sitting next to strangers. Less oppositional than when a process of criticism is engaged, this politics is not necessarily less able to bring about social change. It may just take time and the doing and doing again of affirmative, embodied interventionist acts.

In company with Manning (2016, p.8), I define the political as 'the movement activated, in the event, by a difference in register that awakens new modes of encounter and creates new forms of lifegiving'. It is affect that largely does this activating and awakening, as evidenced in Joseph's 'handson' and capacious relationship with working class cottages. A politics of affect has the potential to undo normative power relations and address enduring issues of social inequality and do so in affirmative, forward-looking ways. On a personal note, my powers of acting as a researcher as a result of the encounter had with this politics in this paper, are greatly increased. It is the movement 
towards affirmation engendered through and in this encounter that is particularly key to boosting these powers.

\section{References}

Ahmed, S. (2010). This other and other others. Economy and Society, 31(4), pp. 558-572.

Ahmed, S. (2014). The cultural politics of emotion (2nd ed.) Edinburgh: Edinburgh University Press.

Anderson, K., \& Perrin, C. (2015). New materialism and the stuff of humanism. Australian Humanities Review, 58, pp. 1-15.

Andrews, G. J. (2019). Health geographies II: The posthuman turn. Progress in Human Geography, 43(6), pp. 1109-1119.

Barad, K. (2007). Meeting the universe halfway: Quantum physics and the entanglement of matter and meaning Durham, NC: Duke University Press.

Bolanos, P. (2007). Nietzsche, Spinoza, and the Ethological Conception of Ethics. Minerva: An Internet Journal of Philosophy, 11, pp. 113-127.

Braidotti, R. (2009). On putting the active back into activism. New Formations, 68(16), pp. 42-57.

Braidotti, R. (2013). The posthuman Cambridge, UK ; Malden, MA Polity.

Braidotti, R. (2015). Posthuman affirmative politics. In S. E. Wilmer \& A. Žukauskaite (Eds.), Resisting Biopolitics: Philosophical, Political, and Performative Strategies (pp. 30-56): Taylor \& Francis Group.

Braidotti, R. (2018). Affirmative ethics: Posthuman subjectivity, and intimate scholarship: A conversation with Rosi Braidotti. In K. J. Strom, T. Mills \& A. Ovens (Eds.), Decentering the Researcher in Intimate Scholarship: Critical Posthuman Methodological Perspectives in Education, Vol. 31 (pp. 112-118). Bingley, UK: Emerald Publishing Limited.

Braidotti, R. (2019a). Affirmative ethics and generative life. Deleuze and Guattari Studies, 13(4), pp. 463-481. doi:10.3366/dlgs.2019.0373

Braidotti, R. (2019b). Posthuman knowledge Oxford, United Kingdom: Polity Press.

Braidotti, R., Dernikos, B. P., Lesko, N., McCall, S. D., \& Niccolini, A. D. (2020). Passion, pedagogy and pietas: An Interview With Rosi Braidotti. In B. P. Dernikos, N. Lesko, S. D. McCall \& A. D. Niccolini (Eds.), Mapping the Affective Turn in Education: Theory, Research, and Pedagogy (pp. 39-53). New York: Routledge.

Colebrook, C. (2002). Understanding Deleuze Crows Nest, NSW: Allen \& Unwin.

Deleuze, G. (1988). Spinoza: Practical philosophy (R. Hurley, Trans.) San Francisco: City Lights Books.

Deleuze, G., \& Guattari, F. (1987). A thousand plateaus: Capitalism and schizophrenia (B. Massumi, Trans.) Minneapolis and London: University of Minnesota Press.

Dernikos, B. P., Lesko, N., McCall, S. D., \& Niccolini, A. D. (2020). Feeling education. In B. P. Dernikos, N. Lesko, S. D. McCall \& A. D. Niccolini (Eds.), Mapping the affective turn in Education: Theory, research, and pedagogy (pp. 3-27). New York: routledge.

Dolphijn, R., \& van der Tuin, I. (2012). New materialism: Interviews \& cartographies Ann Arbor, Michigan: Open Humanities Press.

Ellingson, L. L., \& Sotirin, P. (2020). Making Data in Qualitative Research: Engagements, Ethics, and Entanglements London: Routledge.

Fox, N. J., \& Alldred, P. (2018). New materialism. In P. A. Atkinson, S. Delamont, M. A. Hardy \& M. Williams (Eds.), The SAGE Encyclopedia of Research Methods. London: Sage. 
Gregorio, M. D., \& Merolli, J. L. (2016). Introduction: Affective citizenship and the politics of identity, control, resistance. Citizenship Studies, 20(8), pp. 933-942. doi:10.1080/13621025.2016.1229193

Guattari, F.-P. (1996). The Guattari Reader Oxford: Blackwell Publishers Ltd. .

Hemmings, C. (2005). Invoking affect: Cultural theory and the ontological turn. Cultural Studies, 19(5), pp. 548-567. Retrieved from https://doi.org/10.1080/09502380500365473

MacLure, M. (2018). The "new materialisms": A thorn in the flesh of critical qualitative inquiry? In G. S. Cannella, M. S. Pérez \& P. A. Pasque (Eds.), Critical Qualitative Inquiry: Foundations and Futures (pp. 93-112). Walnut Creek, CA: Left Coast Press.

Manning, E. (2007). Politics of touch: Sense movement sovereignty Minneapolis: University of Minnesota Press.

Manning, E. (2016). The minor gesture Durham amd London: Duke University Press.

Massumi, B. (2015). Politics of affect Cambridge, UK: Polity Press.

Mol, A. (2002). The body multiple: Ontology in medical practice Durham, NC: Duke University Press.

Moss, P., Kern, L., Hawkins, R., \& Falconer Al-Hindi, K. (2018). Grasping the affirmative: Power and the process of becoming joyful academic subjects. Emotion, Space and Society, 28, pp. 5359.

Nelson, J. K. (2020). Intimate interventions: Responses to racist talk in families. Emotion, Space and Society, 35, pp. 1-7.

Orlikowski, W. J., \& Scott, S. V. (2015). Exploring material-discursive practices. Journal of Management Studies, 52(5), pp. 697-705.

Ringrose, J., Warfield, K., \& Zarabadi, S. (Eds.). (2019). Feminist Posthumanisms, New Materialisms and Education. New York: Routledge.

Smith, L. (2021). Emotional Heritage: Visitor Engagement at Museums and Heritage Sites Abingdon, Oxon; New York, NY: Routledge.

Snaza, N., Sonu, D., Truman, S. E., \& Zaliwska, Z. (Eds.). (2017). Pedagogical matters: New materialisms and curriculum studies. New York: Peter Lang.

Sparrow, T. (2010). A physiology of encounters: Spinoza, Nietzsche, and strange alliances. Epoché, 15(1), pp. 163-184.

Spinoza, B. (1994). Ethics (E. Curley, Trans.) New Jersey: Princeton University Press.

Stephano, O. (2017). Spinoza, Ecology, and Immanent Ethics: Beside Moral Considerability. Environmental Philosophy, 14(2), pp. 317-338. Retrieved from https://www.pdcnet.org//pdc/bvdb.nsf/purchase?openform\&fp=envirophil\&id=enviroph il 20170014000203170338

Taylor, K.-Y. (Ed.). (2017). How We Get Free: Black Feminism and the Combabee River Collective. Chicago, Illinois: Haymarket Books.

Thiele, K. (2014). Ethos of Diffraction: New Paradigms for a (Post)humanist Ethics. Parallax, 20(3), pp. 202-216.

Thrift, N. (2004). Intensities of feeling: Towards a spatial politics of affect. Geografiska Annaler, 86(1), pp. 57-78.

von Scheve, C. (2018). A social relational account of affect. European Journal of Social Theory, 21(1), pp. $39-59$.

Wise, J. M. (2011). Assemblage. In C. J. Stivale (Ed.), Gilles Deleure: Key Concepts (Second edition ed., pp. 91-102). Durham: Acumen Publishing Limited.

Witcomb, A. (2015). Toward a pedagogy of feeling: Understanding how museums create a space for cross-cultural encounters. In A. Witcomb \& K. Message (Eds.), The International Handbooks of Museum Studies: Museum Theory (pp. 321-344). Malden, Oxford, Chichester: John Wiley \& Sons. 
Zembylas, M. (2006). Witnessing in the classroom: The ethics and politics of affect. Educational Theory, 56(3), pp. 305-324.

Zerilli, L. M. (2015). The turn to affect and the problem of judgment. New Literary History, 46(2), pp. 261-286. 


\section{University Library}

\section{- M M N E R VA A gateway to Melbourne's research publications}

Minerva Access is the Institutional Repository of The University of Melbourne

Author/s:

Mulcahy, D

Title:

A politics of affect: Re/assembling relations of class and race at the museum

Date:

2021-02-19

Citation:

Mulcahy, D. (2021). A politics of affect: Re/assembling relations of class and race at the

museum. Emotion, Space and Society, 39, https://doi.org/10.1016/j.emospa.2021.100773.

Persistent Link:

http://hdl.handle.net/11343/263712 